\title{
A construção não tonal da canção Jóia de Caetano Veloso
}

\author{
Marcelo Segreto (USP, São Paulo, SP) \\ marcelosegreto@yahoo.com.br
}

Resumo: Estudo sobre a relação entre o texto linguístico e o texto musical na canção Jóia de Caetano Veloso. São analisados os procedimentos composicionais não tonais presentes na obra em consonância com o sentido de sua letra. Este estudo faz parte de uma pesquisa mais ampla que analisou canções populares em que o plano harmônico se distanciava da tonalidade.

Palavras-chave: canção popular; música popular não tonal; harmonia modal; Caetano Veloso.

\section{The non-tonal construction in the song Jóia by Caetano Veloso}

Abstract: Study about the relation between the poetical and the musical text in the song Jóia by Brazilian singercomposer Caetano Veloso. The non-tonal compositional procedures are analyzed in accordance to the lyrics' meaning. This study is part of a larger research project concerning popular songs in which harmony was distanced from tonality.

Keywords: popular song; non-tonal music; modal harmony; Caetano Veloso.

\section{Introdução}

A canção Jóia de Caetano Veloso, gravada no LP de mesmo nome (VELOSO, 1975), é um exemplo claro de uma composição popular baseada em um pensamento musical não tonal. Mas o interesse por este tipo de construção musical, ao invés da criação mais convencional de uma melodia acompanhada por uma harmonia de acordes, não é, neste momento, um fato novo na obra do compositor. 0 disco Araçá Azul (VELOSO, 1973) já realiza experimentações com a linguagem musical através de variados recursos: colagens, sobreposição de vozes, mudanças na velocidade de gravação, inversão da rotação, entre outras técnicas da música eletroacústica. 0 que nos interessa aqui é verificar de que maneira, na canção Jóia, a partir de procedimentos mais sonoros do que harmônicos, se estabelece a relação íntima entre a música e a letra.

\section{Aspectos da letra da canção}

Jóia

Beira de mar

Beira de mar

Beira de maré na América do Sul

Um selvagem levanta o braço

Abre a mão e tira um caju

Um momento de grande amor

De grande amor

Copacabana

Copacabana

Louca total e completamente louca

A menina muito contente

Toca a coca-cola na boca

Um momento de puro amor

De puro amor 
Se observarmos a letra isoladamente já podemos identificar uma clara simetria entre as suas duas estrofes. Elas expõem duas cenas contrastantes e similares ao mesmo tempo. Ao colocá-las em diálogo no espaço da canção, a letra explora este jogo de semelhanças e diferenças que, ao final, revela um sentido comum aos dois momentos retratados. Vejamos então de que maneira este jogo se desenrola.

Se tomarmos os três primeiros versos das duas estrofes, veremos que eles exercem funções referenciais semelhantes, determinando para o ouvinte o espaço geográfico específico onde o breve momento descrito a frente se ambientará.

\author{
Beira de mar \\ Beira de mar \\ Beira de maré na América do Sul \\ Copacabana \\ Copacabana \\ Louca total e completamente louca
}

Os dois primeiros versos de cada estrofe já têm entre si uma diferença significativa: o termo "beira de mar" é mais geral do que "Copacabana". 0 primeiro aparece despido das informações culturais que o segundo nos suscita. "Copacabana" é nome próprio de uma conhecida praia carioca. Nome que tem origem em um elemento da cultura ocidental (a denominação teria surgido devido à igreja de Nossa Senhora de Copacabana fundada no local). "Beira de mar", por sua vez, nos indica um lugar mais indeterminado, como se representasse qualquer praia da América do Sul (não ignoremos, contudo, a sugestão de uma identificação entre os dois espaços, já que "beira de mar" pode representar a própria praia de Copacabana em um período histórico anterior à chegada dos portugueses). No terceiro verso de ambos os fragmentos, temos um movimento semelhante em direção a uma especificação do sentido: a beira de mar da qual se fala é na América do Sul e a Copacabana da qual se fala é aquela que é "louca total e completamente louca". 0 espaço se constitui a partir da maneira como as personagens (selvagem e menina) e as sociedades representadas por eles (povos indígenas e Brasil contemporâneo) interagem com o ambiente em questão. 0 lugar do selvagem não tem nome. Seu espaço é grandioso, pois não se define: pode ser uma praia específica como Copacabana ou o litoral brasileiro inteiro. 0 lugar da menina é nomeado, tem história e, além disso, se refere a uma Copacabana também específica, mergulhada na euforia dos jovens dos anos setenta. 0 verso "Louca total e completamente louca" usa da redundância para sublinhar esta euforia. A repetição do sentido de "louca total" em "completamente louca", além de reforçar a intensidade desta loucura, dá ao verso uma forma irreverente (ou louca), assim como quer expressar o seu conteúdo. Além disso, o fato do verso começar e terminar com a palavra "louca" também contribui para o sentido de completude (louca do início ao fim) que a letra nos indica.
Nos dois versos seguintes de cada estrofe temos o que seria o núcleo de cada uma das cenas. Neles os personagens, já ambientados em seus respectivos espaços, executarão suas pequenas ações que serão avaliadas pelo "narrador" (nos dois últimos versos) como momentos preciosos.

Um selvagem levanta o braço
Abre a mão e tira um caju

A menina muito contente

Toca a coca-cola na boca

Observamos novamente a oposição entre as duas estrofes. As diferenças quanto ao grau de determinação também se fazem presentes nos termos "um selvagem" e "a menina". Um é artigo indefinido e $a$ é definido (além da diferença de gênero, masculino e feminino). Temos novamente a indefinição para o item da primeira estrofe e a definição para o componente da segunda. 0 levantar do braço do selvagem para colher a fruta na árvore, diretamente da natureza, nos sugere um gesto de certa forma sagrado. Como uma homenagem ao divino, estendendo os braços e tocando a fruta que vem do alto. Sentimos esta personagem em harmonia absoluta com seu ambiente. $A$ menina, por sua vez, caracterizada como "muito contente", também entra em consonância com seu espaço cujo clima é de euforia geral. "Louca total e completamente louca" é a Copacabana retratada na canção. Sua ligação com o ambiente, entretanto, já não se faz através de um contato direto com a natureza propriamente dita (o caju como fruto nativo do Brasil), mas sim com um objeto industrializado e símbolo da cultura norte-americana presente em todo o globo. Falaremos disso mais a frente. Por ora basta assinalarmos que o contato harmonioso da menina com o seu mundo, através da coca-cola, é valorizado na letra pelas aliterações do verso "Toca a coca-cola na boca". Pois este recurso aproxima fortemente (pela semelhança sonora gerada pela repetição das sílabas "to", "co" e "ca") todos os elementos que compõe esta cena: a ação (toca), o objeto (coca-cola) e a personagem (boca). Vale dizer que esta característica sonora já está presente no verso anterior (na palavra "contente"). Assim, a harmonia presente no plano do conteúdo também se mostra nos elementos formais da letra desta canção. Sigamos em frente.

\section{Um momento de grande amor \\ De grande amor \\ Um momento de puro amor \\ De puro amor}

Apesar da distância temporal/social extrema entre os dois momentos descritos na letra (o fruto colhido no pé pelo selvagem e o refrigerante industrializado na boca da menina), ambos são caracterizados de forma muito próxima. Parecem significar um único acontecimento: no mesmo espaço (mas separados no tempo), o mesmo gesto, o mesmo amor. A atmosfera geral da canção (produzida também por seu plano musical de repetições rítmicas e melódicas) contribui para que os dois ambientes se entrecruzem, se contaminem. Por isso, no último verso 
da segunda estrofe, o momento vivido pela menina é de puro amor, mas também de grande amor. Em verdade, parece tratar-se do mesmo amor grande e puro, este amor do selvagem e da menina. Comparando as duas estrofes, observamos que este é o único ponto onde encontramos uma repetição de vocábulos, onde os versos coincidem: no mesmo segmento de melodia temos as frases "Um momento de puro amor/De puro amor" e "Um momento de grande amor/De grande amor". A única alteração é a troca do adjetivo "grande" por "puro". Desse modo, o fato destes versos praticamente permanecerem iguais em ambas as estrofes pode ser sinal de que o compositor deseja aproximar as duas situações às quais eles se referem. Além disso, a expressão "um momento" usada nas duas estrofes também nos sugere a possibilidade de se tratar de apenas um momento, isto é, do mesmo momento (instante em que os gestos não estariam mais separados pelo tempo).

Os dois personagens perfazem o mesmo gesto e ambos são puros e grandes no amor com que o realizam. Observamos neste ponto uma manifestação clara da proposta estética e ideológica do tropicalismo, de assimilar num único espaço elementos ou experiências tidas como contrárias. Tendo em vista o período histórico em que esta canção se insere (momento ainda de forte engajamento político e oposição maniqueísta entre a "cultura brasileira autêntica" e a "cultura norte-americana imperialista e alienante"), podemos vislumbrar com maior precisão o sentido da letra desta canção para os ouvintes da época. Esta equivalência entre o elemento nacional "puro" (o caju nativo do Brasil) e a "impureza" do elemento estrangeiro (a coca-cola símbolo do imperialismo norte-americano) não deixa de ser uma provocação a certa parcela da esquerda nacionalista, assim como as guitarras elétricas nos polêmicos festivais da música popular brasileira dos anos sessenta. Nesse sentido, a expressão "puro amor" usada para caracterizar o instante de ação da menina ganha certa carga de ironia. Pois o adjetivo seria mais adequado, como querem os "puristas", ao momento do selvagem e não ao gesto da personagem cuja cultura é "impura" e completamente louca: uma mistura de elementos locais e estrangeiros.

0 que nos importa aqui, entretanto, é apenas assinalar este elo entre os dois instantes. Ligação que também estará presente no plano musical da canção. Selvagem e menina entram numa conjunção mágica com o ambiente que os circunda. E nesse momento ambos os objetos (tanto a fruta como a coca-cola, que são o mesmo objeto afinal) são autênticos, pois através deles manifestou-se um amor igualmente autêntico, grande e puro: a coca-cola é assim tão natural quanto o caju. Mais vale a intensidade e preciosidade do sentimento (sentido já contido no próprio significado da palavra jóia) do que o meio pelo qual ele brotou.

\section{Aspectos musicais da canção}

Também sentimos essa ligação entre as duas cenas (elo no tempo, no espaço, no gesto) através dos elementos musicais presentes na canção. As duas estrofes são entoadas exatamente com a mesma melodia e a canção inicia e termina em fade in e fade out, como se sempre existisse ou fosse infinita. Como se fôssemos nós que nos aproximássemos dela, ela que sempre esteve ali (mais um elemento que ajuda a construir um sentido especial para o tempo). É evidente, desde a primeira escuta, uma forte referência à música não ocidental: não temos aqui a presença fundadora da tonalidade com uma melodia construída sobre um caminho harmônico de acordes progredindo através de tensões e relaxamentos. Ao contrário, temos a impressão de algo de certa maneira estático, uma música elaborada a partir da sobreposição de ritmos e vozes sem um pensamento harmônico tonal. A escolha da instrumentação, a forma não "tradicional" e a reiteração rítmica e melódica nos remetem sem dúvida à música oriental como, por exemplo, do gamelão da ilha de Bali. Tendo em vista o sentido da letra comentado acima, nada parece mais adequado do que esta sonoridade não ocidental, sempre ligada à coletividade e ao contato intimo com o ambiente:

Essa música é a expressão imediata, primitiva, de uma cultura coletiva. Profundamente integrada à vida social, é uma maneira de ser e de agir, em harmonia com a natureza. (CANDÉ, 2001, p.162)

Em 0 som e o sentido, José Miguel Wisnik assinala 0 caráter circular das construções rítmicas e melódicas desta música não tonal e a singular experiência do tempo que ela proporciona. E este aspecto temporal ligado à circularidade, a meu ver, é importante na construção do sentido de letra e música nesta canção de Caetano Veloso.

(...) as melodias participam da produção de um tempo circular, recorrente, que encaminha para a experiência de um não tempo ou de um "tempo virtual", que não se reduz à sucessão cronológica nem à rede de causalidades que amarram o tempo social comum. (WISNIK, 1989, p.78)

Esta "experiência de um não tempo" é um elemento que também fortalece o elo comentado acima entre os episódios do selvagem e da menina, transformando-os num único momento, estes momentos únicos. Vejamos então a partir dos diferentes aspectos musicais (ritmo, melodia e "harmonia") como se manifesta esta circularidade.

Quanto ao ritmo, Wisnik observa como característica da música não europeia, uma estrutura formada pela sobreposição de figuras rítmicas irregulares, mas recorrentes, girando em torno de um centro, isto é, de um pulso (WISNIK, 1989, p.78). Em Jóia este tipo de procedimento é bastante evidente: observamos uma forte regularidade rítmica devido à repetição das figuras pelos instrumentos de percussão e pela presença de uma nota pedal. Entretanto, dentro desta regularidade geral também encontramos padrões rítmicos variados. Como podemos constatar no Ex.1, há em Jóia uma significativa valorização da pulsação: a primeira linha inferior da percussão marca ao longo de toda a canção um pedal sobre a nota mi, elemento básico sobre o qual os demais padrões rítmicos se apoiarão'. Além disso, com exceção de algumas passagens com síncopas e tercinas, todos os instrumentos, inclusive as vozes, reiteram em graus variados este mesmo pulso fundamental. No entanto, 
apesar da valorização da pulsação, nos chama a atenção a combinação de figuras irregulares. As vozes e o pandeiro/ platinelas predominantemente dividem a pulsação binariamente através de colcheias. Já o atabaque divide o pulso em tercinas e o bongô divide de forma ternária o espaço equivalente a duas pulsações. Interessante notarmos esta ambivalência rítmica: figurações distintas que ao mesmo tempo se chocam e se combinam em prol de um tempo fundamental.

Sobre esta questão da irregularidade rítmica também podemos destacar a sua presença na própria melodia da canção comparando-a com os padrões rítmicos dos instrumentos de percussão (Ex.2).

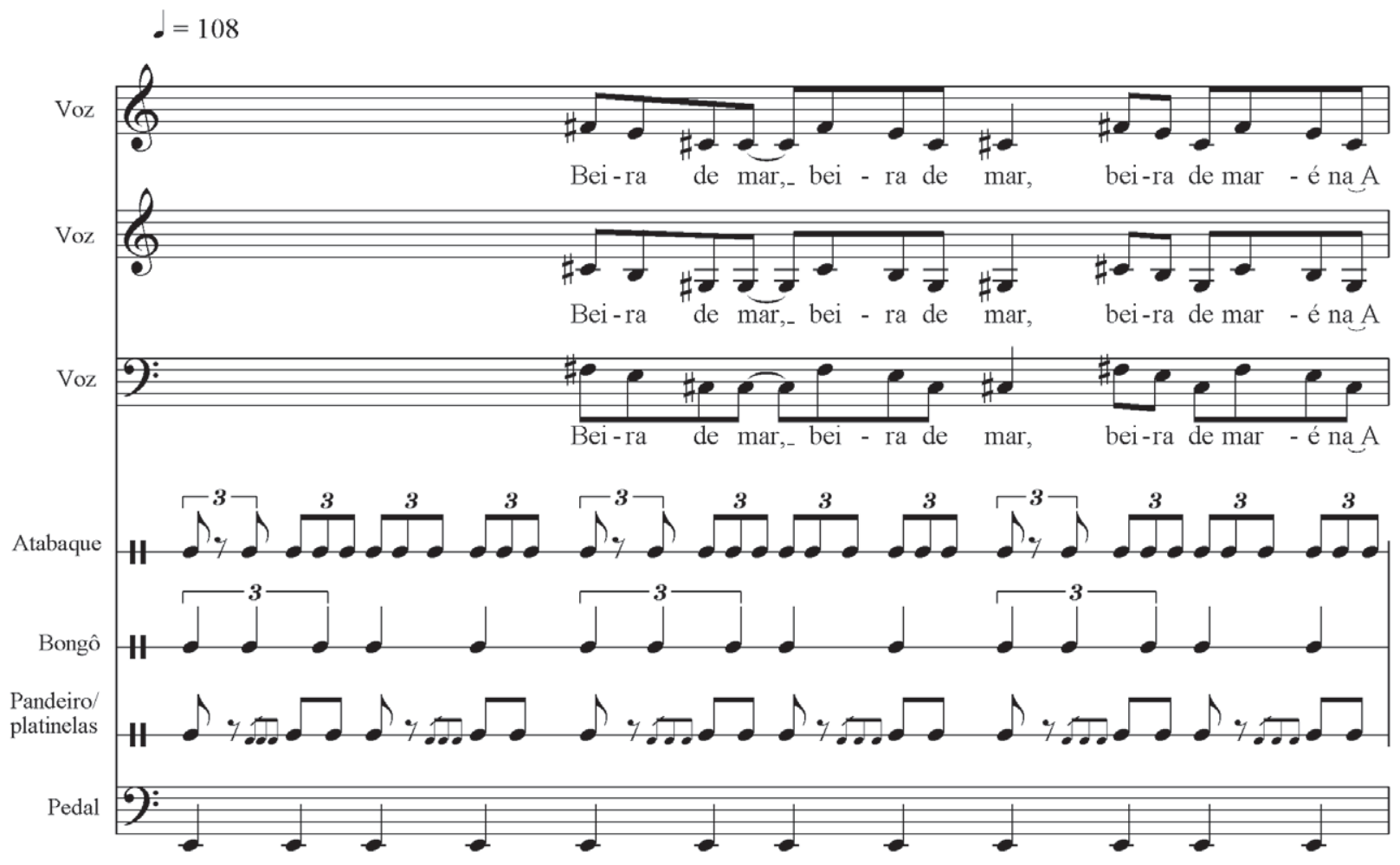

Ex.1 - Pulsação e divisão rítmica em Jóia de Caetano Veloso (regularidade e irregularidade).

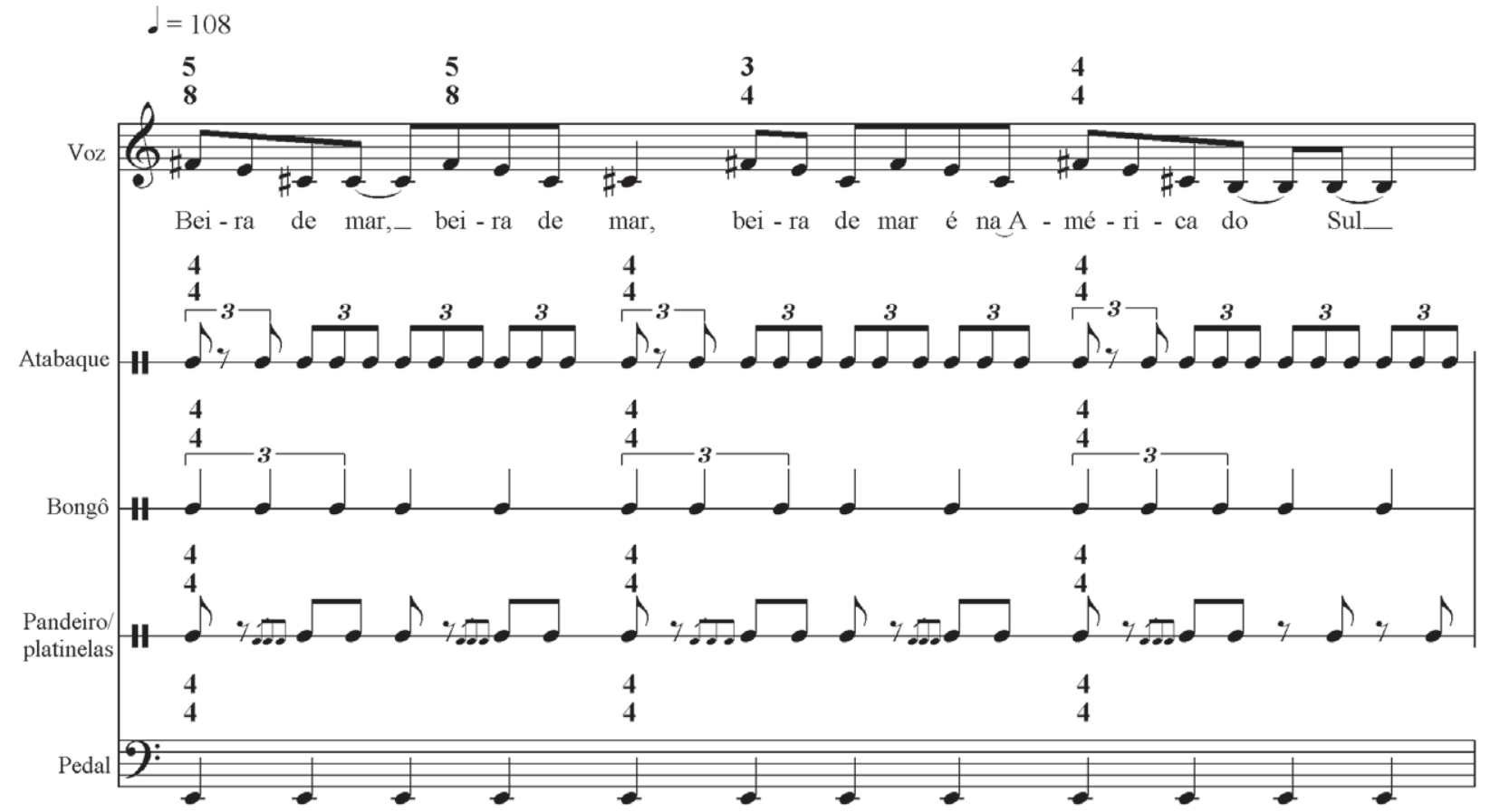

Ex.2 - Irregularidade métrica do canto em oposição à regularidade dos instrumentos de percussão em Jóia de Caetano Veloso. 
Como observamos no Ex.2, ao contrário das quatro linhas da percussão (que apesar das figurações ternárias comentadas acima, realizam ciclos rítmicos perfeitamente adequados a um compasso quaternário), a melodia da voz, devido à irregularidade de seus acentos, parece alternar as indicações métricas dos compassos. Temos então, equivalendo aos dois primeiros compassos quaternários da percussão, o que seriam dois compassos 5/8 e um compasso 3/4. Este tipo de procedimento, segundo Stefan Kostka, é mais comum no repertório musical do século XX do que no período anterior ligado à música tonal. 0 autor destaca que estas mudanças nas indicações métricas "podem estar implícitas por haver um deslocamento de acentos ou pelo uso de síncopas" (KOSTKA, 2006, p.116). Kostka, ao tratar da música escrita do século $X X$, se refere aqui ao caso em que o compositor não escreve as indicações das fórmulas de compasso deixando essa variação se fazer implicitamente através dos acentos. No caso desta canção, que não foi concebida dentro de uma tradição escrita, vale apenas destacar a significativa utilização desses acentos métricos não usuais da melodia em contraste com os acentos mais regulares da percussão, fator que também contribui para o afastamento de Jóia em relação à música ocidental tonal.

0 elemento rítmico é tão decisivo nesta canção que mesmo a sua construção melódica é fortemente influenciada por ele. Como observa Wisnik, na cultura musical não ocidental, as melodias não formam os temas tão característicos da tonalidade e estão de certa maneira relacionadas a um apelo igualmente rítmico:

\footnotetext{
Além da trama ritmico-melódica, uma outra coisa contribui para converter a ordem melódica em ordem da pulsação: na música modal não há temas individualizados, como haverá claramente na música tonal. As melodias são manifestações da escala, desdobramentos melódicos que põem em cena as virtualidades dinâmicas do modo, mais do que motivos acabados que chamam a atenção sobre si. Através das melodias a escala circula, e essa circulação é uma modalidade de ritmo, enquanto figura de recorrência. (WISNIK, 1989, p.79)
}

Em Jóia, percebemos claramente este procedimento melódico apontado pelo autor. As suas melodias parecem mais manifestações "brutas" dos modos empregados do que propriamente formações temáticas construídas a partir dessas escalas. Assim, o modo está presente de maneira mais explícita na melodia, talvez até pela predominância de graus conjuntos. E este vagar pelas notas da escala, como apontou Wisnik, se relaciona a uma ideia de circularidade e recorrência que é importante para o sentido da canção como um todo: contribui para o efeito mencionado anteriormente de união entre os dois acontecimentos (do selvagem e da menina) num único gesto de puro amor.

Na melodia de Jóia observamos o uso de duas escalas ou fragmentos dessas escalas: a pentatônica, formada pelos intervalos de $2^{\text {a }}$ maior e $3^{\text {a }}$ menor (modo que predomina na canção de Caetano Veloso); e a escala de tons inteiros, formada somente por intervalos de $2^{\text {a }}$ maior e usada no trecho central da canção. 0 Ex.3 mostra a ocorrência desses modos em cada segmento da melodia/letra.

Interessante notar que a escolha dos modos, sobretudo no uso mais frequente da pentatônica, além de remeter novamente à cultura sonora oriental ou africana, condiz a uma música que pretende trabalhar com aspectos não propriamente tonais: tanto na escala pentatônica quanto na escala de tons inteiros qualquer uma de suas alturas pode ser um centro de convergência. Nenhuma nota tem a priori a condição de tônica. Além disso, ambos os modos apresentam limitações para a construção de acordes, desfavorecendo um trabalho musical mais harmônico. Também é necessário assinalar que o uso de diferentes escalas e até mesmo o fato de aparecerem incompletas são fatores que também aproximam esta canção de expressões musicais distantes da tonalidade.

No século $X X$ é raro encontrarmos uma peça inteira que use uma só escala (com exceção das escalas cromática e microtonal). 0 que é comum, ao contrário, é nos defrontarmos com uns poucos

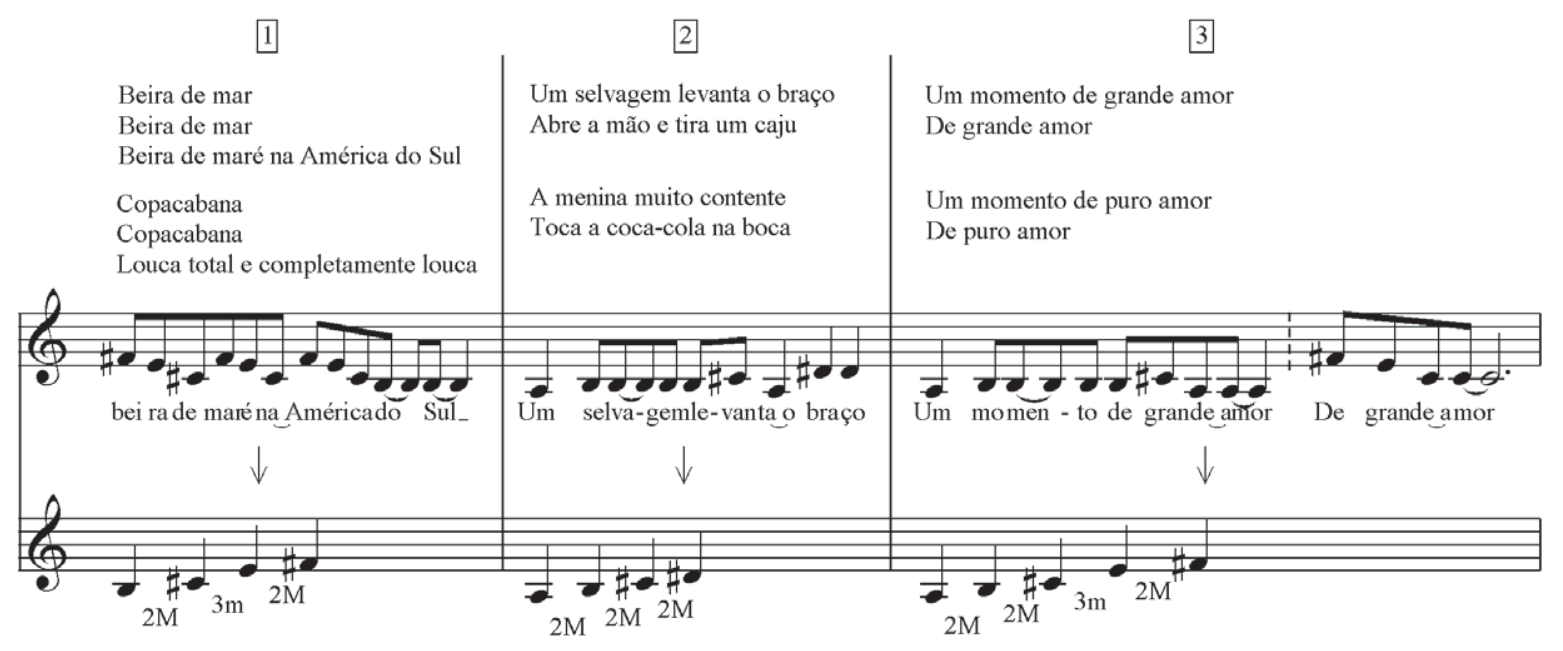

Ex.3 - Características escalares em Jóia de Caetano Veloso: predomínio da escala pentatônica (fragmentos 1 e 3) e sugestão da escala de tons inteiros com a presença da nota Ré\# (fragmento 2). 
compassos fazendo uso de uma única escala; ou com uma melodia composta de acordo com uma determinada escala enquanto o acompanhamento não faz uso da mesma escala; ou ainda, a peça pode incluir umas poucas alturas que fazem alusão a uma determinada escala. (KOSTKA, 2006, p.22)

0 fato da escala pentatônica não possuir uma tônica fixa não apenas favorece um trabalho musical alternativo à tonalidade, mas também é significativa para o caráter de circularidade da música e da letra de Jóia. Segundo Wisnik, esta escala já é internamente circular:

0 princípio do rodizio do centro, no caso da escala pentatônica (entendida como proto-escala do mundo modal), é intimamente unido à própria ordem sonora, pois a circularidade está inserida na sua própria estrutura: nela, cada nota pode ser indiferentemente o princípio, o fim ou o meio de um motivo melódico, todas podem estar num ponto qualquer do caminho (como nota de passagem), ou então soar já como nota final, que encerra e conclui o motivo. (WISNIK, 1989, p.79)

Observamos então que a ideia de circularidade está presente em diversos elementos convocados pela canção: no sentido temporal que a letra sugere, nos aspectos rítmicos, nas melodias, na própria constituição interna da escala adotada. Vejamos agora de maneira mais detida como se dá a relação entre esta estrutura melódica baseada nestas escalas com o texto poético de Jóia. Como observamos no Ex.3, no primeiro segmento de cada uma das duas estrofes, são usados fragmentos de escalas pentatônicas. Na verdade, o trecho circula principalmente sobre três notas de uma escala pentatônica construída a partir da nota Lá (cuja configuração só se completará mais a frente): Fá\#, Mi e Dó\# (pensando no pentagrama superior). A nota Si aparece apenas ao final do segmento. É interessante destacar que as melodias que recobrem esta parte inicial da letra nas duas estrofes são descendentes. Assim como a letra que firma uma referência espacial (um chão) para a cena, beira de mar e Copacabana, a melodia também enfatiza este chão a partir de seu perfil descendente. Notamos inclusive que a nota mais grave do segmento (a nota Si) aparece apenas no momento em que estes espaços são mais especificados, mais firmados: a beira de mar é na América do Sul e Copacabana é a completamente louca.

No segundo segmento da letra, quando são enunciados os gestos do selvagem e da menina, é acrescentada uma nota estranha à escala pentatônica (nota Ré\#). Esta nota sugere neste trecho o uso de uma escala de tons inteiros incompleta: Lá-Si-Dó\#-Ré\#. Obviamente, não nos interessa aqui definir por si só a escala utilizada na canção ${ }^{2}$. 0 importante neste caso é ressaltar que esta nota estranha à pentatônica dá a este trecho da letra uma tensão significativa, reforçada ainda pela direção ascendente da melodia. Esta tensão, a meu ver, reforça o sentido de algo que está em ação (os gestos de ambos os personagens). Além disso, tem uma função importante neste núcleo da estrutura da canção já que insere um "problema" a ser solucionado. Uma proposição à espera de uma conclusão, tensão e relaxamento. Quando nos debruçamos sobre o último segmento da letra (quando os gestos do selvagem e da menina são valorizados como momentos de grande e puro amor) percebemos que a escala pentatônica aparece completa (Ex.4).

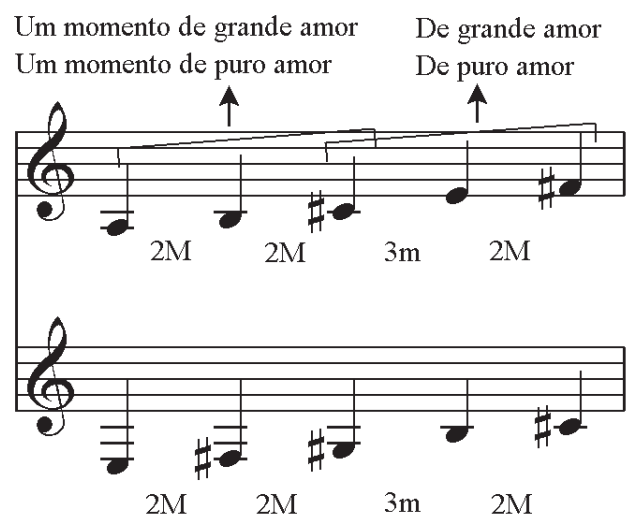

Ex.4 - Escala pentatônica completa na melodia dos últimos versos de cada estrofe em Jóia de Caetano Veloso.

É curioso observar que a escala se completa justamente neste trecho onde está indicado o momento de maior plenitude entre os personagens e seus ambientes. Este sentido de totalidade está presente na pentatônica que aparece integral (Lá-Si-Dó\#-Mi-Fá\#) e sem as "impurezas" de notas estranhas: grande e pura como o amor citado na letra. Além disso, as palavras "puro amor" e "grande amor" são recobertas por melodias descendentes e por isso remetem às melodias/versos iniciais "beira de mar" e "Copacabana". Isso faz com que este amor puro e grande dos dois personagens se ligue mais fortemente aos lugares em que ele se manifesta. Esta repetição melódica do começo no final faz com que a união entre os personagens e seus espaços seja ainda mais forte, mais harmônica, além de reforçar o sentido de circularidade da obra.

Em relação ao resultado polifônico da sobreposição de vozes nesta canção, notamos mais uma vez uma aproximação com a música não ocidental. Em Jóia, as três vozes se

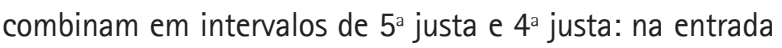
do canto, por exemplo, da mais grave para a mais aguda, temos as notas Fá\#, Dó\# e Fá\# novamente (ver Exemplo 1). E as linhas melódicas se desenvolvem de forma estritamente paralela. Em sua História Universal da Música, Roland de Candé, observa algumas caracteristicas da polifonia vocal na música africana, elementos que se aproximam dos procedimentos usados na canção de Caetano Veloso.

As partes procedem ora por movimento paralelo (terças nas regiões ocidentais e na floresta equatorial, quartas e quintas nas regiões orientais), ora por imitação canônica ou pelo procedimento do ostinato (CANDÉ, 2001, p.165).

0 mesmo autor ilustra essa passagem com um exemplo musical a quatro vozes pertencente ao canto Tonga praticado na região africana da Rodésia -atual Zimbábue (Ex.5). Assim como em Jóia, observamos a predominância

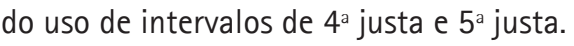



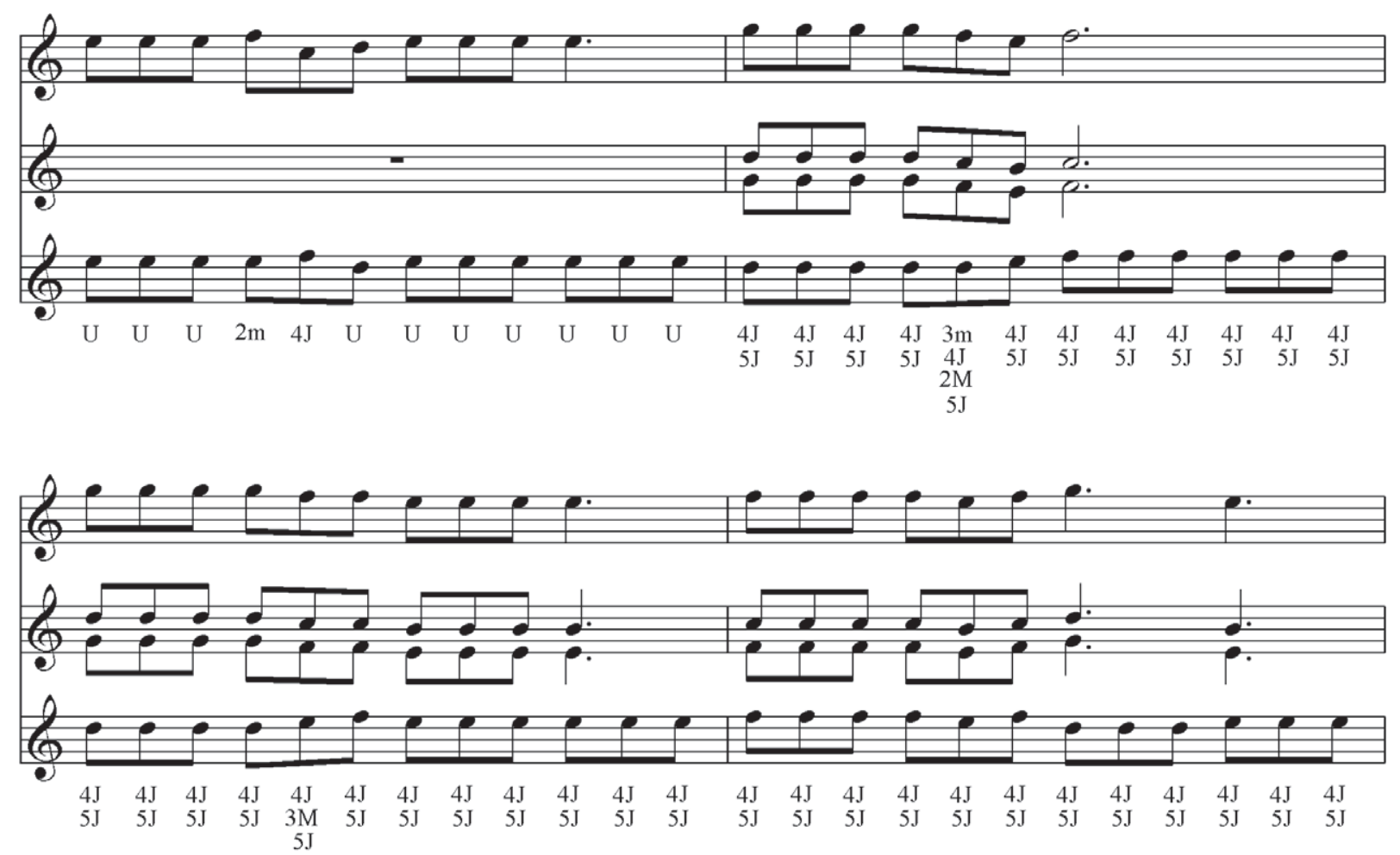

Ex.5 - Canto Tonga na Rodésia, com predominância do uso de intervalos de 4a J e 5a J. (CANDÉ, 2001, v.1, p.165).

Em Jóia, o paralelismo na sobreposição das vozes e a escolha intervalar (além, é claro, de outros aspectos como o ritmo e a melodia já citados anteriormente) contribuem para um efeito de certa "estaticidade harmônica", se pensarmos na ausência das funções tonais que fariam "progredir" o discurso. Esta estaticidade é um elemento que condiz com a ideia de circularidade já mencionada anteriormente. Algo que se movimenta de maneira circular voltando sempre ao mesmo ponto. Fato que nos remete novamente ao sentido da letra de unir os dois espaços, os dois momentos.

Outro importante fator relacionado à ideia de circularidade é a utilização do chamado bordão, espécie de "tônica" que se repete por toda a música e sobre a qual circulam os ritmos e melodias. Como assinala WISNIK (1989, p.78), este movimento em torno de um "eixo harmônico fixo" é um elemento característico da música não tonal e conduz a uma experiência singular do tempo. Como já observamos, na canção de Caetano este eixo harmônico fixo está representado na repetição da nota Mi na região grave, do início ao fim da obra. É interessante notar a relação entre o texto abaixo de Wisnik sobre a música não ocidental e as características observadas em Jóia: movimento circular em torno de um ponto fixo (pulsação/bordão), estaticidade harmônica, significativa remissão ao chão e sensação diferenciada do tempo (estes últimos, aspectos tão caros para o sentido de sua letra, pela conjunção do espaço e do tempo através dos gestos das duas personagens).

A música indiana faz questão de marcar o bordão (essa lembrança contínua do chão sobre o qual se dança, o solo firme sob os vôos melódicos) usando instrumentos cuja função é exclusivamente a de ressoar um som contínuo, numa estaticidade movente, em pulsações de timbre e intensidade. (...) A tônica fixa é um princípio muito geral em toda a música pré-tonal: explícita ou implícita, declarada ou não, pode-se aprender a ouvi-la, pois ela está lá, como a terra, a unidade indivisa, a montanha que não se move, 0 eixo harmônico contínuo, soando através (ou noutra dimensão) do tempo (WISNIK, 1989, p.80)

\section{Conclusão}

Como ficou claro no decorrer deste artigo, priorizou-se aqui uma análise musical e poética de Jóia. A meu ver, isto foi suficiente para proporcionar uma leitura possivel e coerente desta obra. Outras abordagens, entretanto, devem lançar olhares que desvendem outras facetas desta canção, divergindo ou concordando com a análise proposta aqui ${ }^{3}$. 0 estudo da relação entre melodia e letra realizado por Luiz Tatit ${ }^{4}$, por exemplo, pode reafirmar alguns aspectos mencionados acima. Assim, no que se refere aos três modos de compatibilização entre melodia e letra propostos pelo autor, temos na chamada tematização ${ }^{5}$ o procedimento que predomina na canção Jóia. Pois, como vimos, esta canção apresenta uma evidente reiteração rítmica e melódica que ajuda a materializar a ideia de circularidade tão importante para a sua letra.

a tendência a tematização, tanto melódica como linguística, satisfaz as necessidades gerais de materialização (linguísticomelódica) de uma ideia. Cria-se, então, uma relação motivada entre tal ideia (natureza, baiana, samba, malandro) e o tema melódico erigido pela reiteração (TATIT, 2002, p.23)

Enfim, percebemos ao longo desta análise que muitas características sonoras de Jóia a afastam da tradição de 
composição de canções no Brasil, predominantemente ligada aos procedimentos da tonalidade. Ao invés de uma melodia acompanhada por acordes temos aqui um interesse claramente voltado para o ritmo, para a textura e para o timbre, aspectos importantes na música erudita do século $X X$ e na música não ocidental. Além disso, observamos que esta aproximação com a não tonalidade pode ser feita através de um paralelo mais efetivo com a música oriental e esta relação é muito produtiva na medida em que a circularidade é um elo de sentido entre a letra e a sonoridade geral da canção. Circularidade presente nas figurações rítmicas e no pulso fundamental da percussão, no eixo harmônico do bordão, no início e término em fade in e fade out, na construção melódica, na característica interna da escala pentatônica adotada e no paralelismo da sobreposição de vozes. Circularidade do tempo e do espaço que fazem a ligação entre as duas personagens como se fossem protagonistas de um mesmo momento epifânico.

\section{Referências}

CANDÉ, Roland de. História universal da música. 2a edição. São Paulo: Martins Fontes, 2001.

KOSTKA, Stefan M. Materials and Techniques of Twentieth-Century Music. 3a edição. Upper Saddle River: Prentice-Hall, 2006.

TATIT, Luiz. A canção: eficácia e encanto. São Paulo: Atual, 1986.

TATIT, Luiz. O Cancionista. São Paulo: Edusp, 2002.

VELOSO, Caetano. Araçá Azul. LP 6349054. Philips, 1973.

VELOSO, Caetano. Jóia. LP 6349132. Philips, 1975.

WISNIK, José Miguel. O Som e o Sentido. São Paulo, Companhia das Letras, 1989.

\section{Notas}

1 Trata-se possivelmente da corda mais grave do violão (nota Mi) aqui tocado como instrumento de percussão.

2 A denominação da escala não nos interessa muito aqui. Poderíamos explicar a presença desta nota (Ré\#) como uma característica de modos orientais ou nordestinos que utilizam a quarta aumentada.

3 Esta análise faz parte de uma pesquisa sobra composição de canções populares realizada no Departamento de Música da ECA-USP. Por se tratar de um estudo ligado à área de música optou-se por uma análise mais musical da obra.

40 que seria uma análise baseada na linguagem da canção, diferentemente da análise musical e poética realizada aqui.

5 Na tematização, ao contrário da figurativização (quando a relação entre a melodia e o texto verbal se dá a partir de motivações ligadas à entoação da fala), observa-se uma reiteração rítmica e melódica cuja repetição de padrões sonoros se relaciona a fixação de um tema ou ideia (como em "Garota de Ipanema" em que a melodia reiterada constrói a reiteração do balanço da moça que passa) (TATIT, 1986, p.52).

Marcelo Segreto é compositor, cantor, violonista e pesquisador nascido em São Paulo. Formado em letras pela FFLCH-USP e em música (composição) pela ECA-USP. Atualmente cursa mestrado em linguística pela FFLCH - USP com orientação do Prof. Dr. Luiz Tatit, desenvolvendo pesquisa sobre a linguagem cancional do rap. Formou-se em violão erudito na Universidade Livre de Música - ULM com Éverton Gloeden. Realizou projeto de iniciação científica sobre composição de canções populares com bolsa de estudos da FAPESP sob a orientação do Prof. Dr. Paulo de Tarso Salles. É o compositor e idealizador do grupo Filarmônica de Pasárgada. Foi vencedor da 17a edição do Programa Nascente da USP na categoria música popular com o projeto "Enfartando Tinhorão", do $1{ }^{\circ}$ Festival da canção da Unicamp e do $41^{\circ}$ Festival Nacional da Canção (FENAC). Foi um dos cinco finalistas do $2^{\circ}$ Prêmio Musique do Jornal 0 Estado de S. Paulo/Rádio Eldorado cujas canções foram enviadas ao compositor Tom Zé. Selecionado no edital do ProAC 2011 da Secretaria de Estado da Cultura para gravação de disco, lançou em 2013 o primeiro CD, 0 Hábito da Força, com produção musical de Alê Siqueira e projeto gráfico de Guto Lacaz. Com a Filarmônica de Pasárgada, participou da gravação do EP Tribunal do Feicebuqui do compositor Tom Zé. 